\title{
Genetic variability of broodstocks of Tambaqui (Teleostei - Characidae) from the northeast region of Brazil
}

\section{Variabilidade genética de Tambaqui (Teleostei - Characidae) da região nordeste do Brasil}

\author{
Nelson Mauricio Lopera-Barrero ${ }^{1 *}$; Maria del Pilar Rodriguez-Rodriguez ${ }^{2}$; \\ Darci Carlos Fornari ${ }^{3}$; Emiko Kawakami de Resende ${ }^{4}$; \\ Angela Rocio Poveda-Parra ${ }^{5}$; Graciela Braccini ${ }^{6}$; Felipe Pinheiro de Souza ${ }^{7}$; \\ Pâmela Juliana Furlan ${ }^{7}$; Jayme Aparecido Povh $^{8}$; Ricardo Pereira Ribeiro ${ }^{9}$
}

\begin{abstract}
The objective of this experiment was to evaluate the genetic diversity within three Tambaqui broodstocks (Colossoma macropomum). Eight primers were used to analyze 67 individuals collected from three fish farming in the municipalities: Porto Real do Colégio - Alagoas (PRC), Araujo 1 - Sergipe (AR1) and Araujo 2 - Sergipe (AR2), in Brazil. Differences in the frequencies of 88 fragments and four exclusive fragments in PRC were found. High polymorphism values (from 54.38\% to 64.38\%) and Shannon's index (from 0.33 to 0.37 ) were observed. The AMOVA showed that high variation is within each broodstock. The identity and the genetic distance among the groups ranged from 0.845 to 0.975 and from 0.025 to 0.156 respectively, and the shortest distance was found in the groups PRC x AR1 and PRC $x$ AR2. The genetic differentiation ranged from lower to higher $\left(F_{\text {st }}=0.03\right.$ and 0.178$)$ as well as the migratory number per generation $(\mathrm{Nm}=5.07$ to 12.8$)$. In general, the broodstocks had high intrapopulation variability, and high differentiation and genetic distance within themselves.
\end{abstract}

Key words: Colossoma macropomum, genetic diversity, genetic conservation

\section{Resumo}

O objetivo deste trabalho foi avaliar a diversidade genética de três estoques de tambaqui (Colossoma macropomum). Foram utilizados oito iniciadores para analisar 67 indivíduos, coletados de três pisciculturas nos municípios: Porto Real do Colégio - Alagoas (PRC), Araujo 1 - Sergipe (AR1) e

1 Prof. Dr., Dept ${ }^{\circ}$ de Zootecnia, Programa de Pós-Graduação em Ciência Animal, Universidade Estadual de Londrina, UEL, Londrina, PR, Brasil. E-mail: nmlopera@uel.br

2 Pós-Doutoranda, Universidade Federal dos Vales de Jequitinhonha e Mucuri, UFVJM, MG, Brasil. E-mail: rodrigpilar@gmail. com

3 Diretor Executivo, Genetic Fish Rise, Primavera do Norte, Sorriso, MT, Brasil. E-mail: darci.peixegen@gmail.com

4 Dra $^{\mathrm{a}}$, Pesquisadora, Empresa Brasileira de Pesquisa Agropecuária, EMBRAPA, Centro de Pesquisa Agropecuária do Pantanal, Corumbá, MS, Brasil. E-mail: emiko.resende@embrapa.br

5 Pós-Doutoranda, Dept ${ }^{\circ}$ de Zootecnia, UEL, Londrina, PR, Brasil. E-mail: angelapovedaparra@hotmail.com

${ }^{6}$ Pós-Doutoranda, Dept ${ }^{\mathrm{o}}$ de Zootecnia, Universidade Estadual de Maringá, UEM, Maringá, PR, Brasil. E-mail: gracielabh@ibest. com.br

7 Discentes de Mestrado, Programa de Pós-Graduação em Ciência Animal, UEL, Londrina, PR, Brasil. E-mail: felipeps1991@ gmail.com; pamela.furlan@outlook.com

8 Prof. Dr., Dept ${ }^{\circ}$ de Medicina Veterinária e Zootecnia, Programa de Pós-Graduação em Ciência Animal, Universidade Federal de Mato Grosso do Sul, UFMS, Campo Grande, MS, Brasil. E-mail: jayme.peixegen@gmail.com

9 Prof. Dr., Dept ${ }^{\circ}$ de Zootecnia, Programa de Pós-Graduação em Zootecnia, UEM, Maringá, PR, Brasil. E-mail: rpribeiro@uem.br

* Author for correspondence 
Araujo 2 - Sergipe (AR2), Brasil. Foram encontradas diferenças nas frequências de 88 fragmentos, com quatro fragmentos exclusivos em PRC. Observaram-se altos valores de polimorfismo $(54,38$ a $64,38 \%)$ e índice de Shannon (0,33 a 0,37). A AMOVA mostrou que a maior variação está dentro de cada estoque. A identidade e a distância genética entre os agrupamentos variou de 0,845 a 0,975 e 0,025 a 0,156 , respectivamente, com menor distância entre os agrupamentos PRC x AR1 e PRC x AR2. A diferenciação genética variou de baixa a alta $\left(F_{\mathrm{st}}=0,03\right.$ a 0,178$)$ e o número de migrantes por geração foi baixo a alto $(\mathrm{Nm}=5,07$ a 12,8). De forma geral, os estoques apresentam alta variabilidade intrapopulacional e alta diferenciação e distância genética entre si.

Palavras-chave: Colossoma macropomum, diversidade genética, conservação genética

\section{Introduction}

The aquaculture world has had significant growth in the last 50 year, when the total fish production (ton) ranged from 638,557 in 1950 to estimates above 66.633.253 in 2012. These records suggest a rate higher than verified in other edible animal segments (FAO, 2014). The growth of the fish national produce (fisheries and aquaculture), for example, from 2010 (1.264.000 ton) to 2011 was about $13.2 \%$ with the total of 1.431 .974 tons in 2011. In aquaculture were produced 528.704 tons in 2011. The northeast region had the highest record with the participation of $31.7 \%$ in the national production (454.216 tons) when the regional and continental production was 134,292.6 tons (MINISTÉRIO DA PESCA E AQUICULTURA, 2013).

The tambaqui, Colossoma macropomum (Characiformes: Characidae), is a natural species present in the Amazonas and Orinoco basins (ARAUJO-LIMA; GOULDING, 1997). Despite being a major source of food for riverine communities, at present is classified as overfished or threatened by overexploitation (MINISTÉRIO DO MEIO AMBIENTE, 2015).

Regarding production, tambaqui has prominent position among the main species of Brazilian fish with several factors favoring its cultivation. This species has good potential of growth and productivity, easy reproduction and rusticity (ARAUJO-LIMA; GOULDING, 1997; JACOMETO et al., 2010). Thus, in contrast to the wild populations, tambaqui stocks are increasing in fish farming, characterizing it as the native species most commonly produced in Brazil. Tambaqui is the second most produced fish species in Brazil with 88.719 tons in 2013, representing $22.6 \%$ of total production, only behind the tilapia (169.306 tons). The northeast region produced 12.771 tons of tambaqui in 2013, representing $14.39 \%$ of total produced in the country (IBGE, 2013). In addition to the increase of consumption and production, this growth has been stimulating the creation of breeding programs of the species (OLIVEIRA et al., 2012).

The monitoring populations and fish stocks it is important to obtain positive results in breeding programs (FALCONER, 1987; LOPES et al., 2009) or conservation programs (POVH et al., 2008a). Research have indicated that stock with lower or decreasing genetic variability along the generations can induce endogamy, reduce the adaptability, progenies survivorship (LOPERA-BARRERO et al., 2010a; POVH et al., 2008b), and losses of the genetic potential (MOREIRA et al., 2007). The dominant molecular markers are methods useful in the analysis of the genetic variability of progenitor stocks, progenies and wild fish populations (POVH et al., 2008b, 2009; LOPES et al., 2009; JACOMETO et al., 2010; LOPERA-BARRERO et al., 2010b; AZRITA et al., 2014; BHAT et al., 2014; LOPERA-BARRERO et al., 2014).

The aim of this experiment was to evaluate the genetic diversity of fish broodstocks of $C$. macropomum from several regions in the Northeast Brazil. 


\section{Material and Methods}

Samples from the caudal fins were collected from broodstocks of C. macropomum from fish farming in the municipalities of Porto Real do Colégio - AL (PRC: 27 individuals), Araujo 1 - SE (AR1: 20 individuals) and Araujo 2 - SE (AR2: 20 individuals).

The DNA extraction followed the method described by Lopera-Barrero et al. (2008) when micro tubes with about $0.5 \mathrm{~cm}^{2}$ of fin samples had $550 \mu \mathrm{L}$ lyse buffer $\left(50 \mathrm{mmol} \mathrm{L}^{-1}\right.$ Tris - $\mathrm{HCl}, 50$ mmol L-1 EDTA, $100 \mathrm{mmol} \mathrm{L}^{-1} \mathrm{NaCl}$ and 1\% SDS) and $7 \mu \mathrm{L}$ de proteinase $\mathrm{K}\left(200 \mathrm{mg} \mu \mathrm{L}^{-1}\right)$. All these material was incubated in water bath at $50{ }^{\circ} \mathrm{C}$ for 12 hours. The DNA precipitated with $600 \mu \mathrm{L}$ of $\mathrm{NaCl}$ (5 mol L-1) was centrifuged for $10 \mathrm{~min}$ at $14.645 \mathrm{~g}$. The supernatant with the DNA was transferred to other micro tube $(800 \mu \mathrm{L})$, precipitated with $700 \mu \mathrm{L}$ absolute ethylic alcohol and incubated at $-20^{\circ} \mathrm{C}$ for 1 hour. Thereafter, the DNA was centrifuged, washed with $700 \mu \mathrm{L}$ ethylic alcohol at $70 \%$, suspended in $85 \mu \mathrm{L}$ of the buffer solution TE $\left(10 \mathrm{mmol} \mathrm{L}^{-1}\right.$ Tris pH 8 and 1 mmol L-1 EDTA) and treated with $7 \mu \mathrm{L}$ of RNAse $\left(30 \mathrm{mg} \mathrm{mL}^{-1}\right)$ in water bath at $37^{\circ} \mathrm{C}$ for 1 $\mathrm{hr}$. Soon after, the substance was stored in freezer at $-20^{\circ} \mathrm{C}$.

The DNA was quantified in the Shimadzu spectrophotometer (Shimadzu Corporation, Kyoto, Japan) with absorbance of $260 \mathrm{~nm}$. The samples were diluted to $10 \mathrm{ng} \mu \mathrm{L}^{-1}$. The quality of the DNA was monitored by electrophoresis in agarose gel at $1 \%$ using the buffer TBE $1 \mathrm{X}\left(500 \mathrm{mmol} \mathrm{L}^{-1}\right.$ Tris - $\mathrm{HCl}, 60 \mathrm{mmol} \mathrm{L} \mathrm{L}^{-1}$ boric acid and $83 \mathrm{mmol} \mathrm{L}^{-1}$ EDTA), at 70 volts for 1 hour.

The amplification conditions were based in the methods reported by Williams et al. (1990). The DNA was amplified in the volume of $15 \mu \mathrm{L}$ using the buffer $1 \mathrm{X}$ Tris - KCl, 2 mmol L-1 $\mathrm{MgCl}_{2}, 0.46 \mu \mathrm{mol}$ $\mathrm{L}^{-1}$ of primers, $0.2 \mathrm{mmol} \mathrm{L}^{-1}$ from every $\mathrm{dNTP}$, one unity of Platinum Taq DNA Polymerase (Invitrogen (), Carlsbad, EUA), and 10 ng of the DNA under study. This DNA was denaturized at $94^{\circ} \mathrm{C}$ for $4 \mathrm{~min}$ and soon after was submitted to 40 cycles in which every sample was denaturized at $94^{\circ} \mathrm{C}$ for $1 \mathrm{~min}$, annealing of $30 \mathrm{~s}$ with the primer at $40^{\circ} \mathrm{C}$, and $2 \mathrm{~min}$ for the extension at $72^{\circ} \mathrm{C}$. Next, the final extension was at $72^{\circ} \mathrm{C}$ for $7 \mathrm{~min}$. The reaction was amplified in termocycler Eppendorf Mastercycler Gradient. Ten of 30 primers tested from the kits OPA, OPW and OPX (Operon Technologies Ltd., Valencia, USA) with better definition and reproducibility (OPA01, OPA02, OPW04, OPW05, OPW06, OPX02, OPX03, OPX04) were used.

The amplification products were set apart in agarose gel at $1.5 \%$. Fifteen microliters of the amplified product was used in conjunction with 2 $\mu \mathrm{L}$ of the sample buffer ( $40 \%$ sucrose and $0.25 \%$ bromophenol blue) in horizontal electrophoresis. The electrophoresis was carried out in the buffer TBE 0.5X (45 mmol L-1 Tris Borate and $1 \mathrm{mmol} \mathrm{L}^{-1}$ EDTA) at 70 volts for 4 hours. The quantification and amplification gels were displayed under UV radiation after exposing to ethidium bromate $(0.5$ $\mu \mathrm{g} \mathrm{mL}^{-1}$ ) for 1 hour. The image was photographed using the Kodak EDAS program (Kodak 1D Image Analysis 3.5, New York, USA).

The fragment size from the amplifications was estimate based on the standard ladder of $100 \mathrm{pb}$ (Invitrogen, Carlsbad, USA). The presence or not of fragments with identical size was used to build the similarity matrix based in coefficient of similarity of Jaccard where the code 1 indicate the presence of the fragment and the 0 was its absence. The genetic diversity index of Shannon and the percentage of polymorphic fragments (criterion of 95\%) were obtained by the PopGene program 1.31 (YEH et al., 1999).

The TFPGA 1.3 (MILLER, 1997) program was used to find the distance and genetic identity (NEI, 1978) among the fish broodstocks and the frequency of the fragments was determined by the Exact Test (RAYMOND; ROUSSET, 1995). The Arlequin 3.0 program (EXCOFFIER et al., 2005) was used to determine the genetic differentiation using estimates of the $F_{\text {st }}$ (WEIR; COCKERHAM, 1984), and to 
analyze the molecular variance (EXCOFFIER et al., 1992). To analyze the molecular variance among the broodstocks, they were grouped in pairs using all the combination available following the distribution: PRC x AR1; PRC x AR2 and AR1 x AR2. The significance of these tests was verified by using random permutations ranging 1,000 to 10,000 . The same program determined the migrant number per generation (Nm). The significance of the $F_{\text {st }}$ was evaluated by the $\mathrm{X}^{2}$ test $\left[\mathrm{c}^{2}=2 \mathrm{n} F_{\text {st }}(\mathrm{k}-1)\right.$; GL $=$ (k-1)(s-1)], after Workman and Niswander (1970), where: $n$ is the number of fish in both groups, $k$ is the number of alleles and $\mathrm{s}$ is the number of groups.
The magnitude of the genetic differentiation among the broodstocks was determined based on the Wright (1978) definition with low $\left(F_{\mathrm{st}}=\right.$ from 0 to 0.05$)$, moderate $\left(F_{\text {st }}=\right.$ from 0.051 to 0.15$)$, high $\left(F_{\text {st }}=\right.$ from 0.151 to 0.25$)$ and very high $\left(F_{\text {st }}>0.25\right)$ values.

\section{Results and Discussion}

The eight primers generated 109 fragments ranging from 10 (OPA01, OPA02 and OPW04) to 20 (OPX03) primers. The largest fragment (2072 pb) was obtained from the amplification of the OPW04, OPW05, OPX03 and OPX04, and the shortest (220 pb) from the OPW06 (Table 1).

Table 1. Sequence of primers and nucleotides, percentage of purine bases $(\mathrm{G}+\mathrm{C})$, number of fragments and pair of bases of the fragments in broodstocks of Colossoma macropomum.

\begin{tabular}{lcccc}
\hline Primer & Sequency $\left(5^{\prime} \rightarrow 3^{\prime}\right)$ & $\%$ G + C & Fragments & Pairs of bases \\
\hline OPA01 & CAG GCC CTT C & 70 & 10 & $340-2000$ \\
OPA02 & TGC CGA GCT G & 70 & 10 & $350-1500$ \\
OPW04 & CAG AAG CGG A & 60 & 10 & $450-2072$ \\
OPW05 & GGC GGA TAA G & 60 & 12 & $350-2072$ \\
OPW06 & AGG CCC GAT G & 70 & 16 & $220-1650$ \\
OPX02 & TTC CGC CAC C & 70 & 12 & $300-1300$ \\
OPX03 & TGG CGC AGT G & 70 & 20 & $360-2072$ \\
OPX04 & CCG CTA CCG A & 70 & 19 & $320-2072$ \\
\hline Total & --- & --- & 109 & $100-2072$ \\
\hline
\end{tabular}

Significant differences $(\mathrm{p}<0.05)$ were found in 88 of 109 frequencies. Low frequencies (lower than 0.1000) were found in PRC (3) and AR2 (4) with 28 missing fragments (frequencies of 0.0000 ) in the broodstocks $(\mathrm{PRC}=5 ; \mathrm{AR} 1=14$ and $\mathrm{AR} 2$ $=9$ ). The explanation by the low frequencies and the missing fragments within every broodstocks is the bottleneck (JACOMETO et al., 2010) or the founder effects. The bottleneck is the decrease in the population to a small number of individuals because of non-intention selection due to mate of genetically relative individuals loosing genetic and allelic variability (MOREIRA et al., 2007). Thus, bottleneck prevention has to be the main goal to avoid endogamy and genetic drifting (TAVE, 1999;
POVH et al., 2005). Otherwise, if the broodstock has just a few individuals or the selected individuals do not represent genetically the original population (founder effect) there will be reduction in the genetic variability with low frequencies or missing fragments. Even with the possibility of these effects still present in the current experiment, we may not state that they have affected the frequencies, because either information about the reproductive management in these fish farming or the origin of these individuals is not available.

Twenty-three limiting fragments were found (frequency of 1.000) differently dispersed within every broodstock $(\mathrm{PRC}=5 ; \mathrm{AR} 1=15$ and $\mathrm{AR} 2=3)$ 
in conjunction with six exclusive fragments $(\mathrm{PRC}=$ 4; $\mathrm{AR} 1=1$ and $\mathrm{AR} 2=1$ ). These results, however, indicates that although the low frequency and missing fragments, there is high genetic variability within every broodstock. The genetic variability within the broodstocks based on the Shannon's index and percentage of polymorphic fragments (Table 2) indicated adequacy of variability values in agreement with limiting and exclusive fragments, even considering the missing and the low frequent fragments. These results indicate that the broodstocks format came from large number of individuals or wild populations with high genetic variation allowing the maintenance of the variability, despite the expected reduction in captivity (LOPERABARRERO et al., 2010b).

Table 2. Number of fish (N), Shannon's index (SI), and percentage of polymorphic fragments (PF) in the broodstocks of Colossoma macropomum.

\begin{tabular}{cccc}
\hline Broodstocks & N & SI & PF \\
\hline PRC & 27 & 0.37 & 62.50 \\
AR1 & 20 & 0.33 & 54.38 \\
AR2 & 20 & 0.37 & 64.38 \\
\hline
\end{tabular}

(PRC: Porto Real do Colégio, AL; AR1: Araujo 1, SE; AR2: Araujo 2, SE).

The genetic analyses of tambaqui broodstocks as well as other Brazilian species based on the Shannon's index (SI) and the percentage of polymorphic fragments (PF) had similar results to the current experiment. Jacometo et al. (2010) found in stocks from Rondônia, Sergipe and Mato Grosso States values of IS (Teixeirópolis: 0.45; Neópolis: 0.45 and Sorriso: 0.40 , respectively) and FP (Teixeirópolis: 82.64; Neópolis: 83.33 and Sorriso: 73.61, respectively) higher than in the current analysis. They concluded about the existence of adequate intra-population genetic variability. Lopes et al. (2009) analyzing two stocks of C. macropomum, from Rondônia found values higher for the SI (0.468 and 0.439) and PF (77.0\% and $75.0 \%$ ). They also concluded about the presence of high genetic variability.

The comparative analysis in the different groups using AMOVA indicated that the highest part of the variation is found within every broodstock of $C$. macropomum unlike between them. The distance and the identity genetic in the broodstocks indicate higher genetic distances in the groups PRC x AR2 and AR1 x AR2 (Table 3). These results were corroborated with the values of $\mathrm{F}_{\mathrm{st}}$ and $\mathrm{Nm}$. Based on Wright (1978), they had high genetic differentiation. The high values of genetic identity for PRC x AR1 were also corroborated with low genetic differentiation of Wright (1978) and low fixation index $\left(F_{\text {st }}\right)$ indicating low differentiation for the groups PRC x AR1. However, we detected a higher number of migrants in PRC $x$ AR1 in comparison with the groups PRC $\mathrm{x}$ AR2 and AR $1 \mathrm{x}$ AR2 that had the highest values of $\left(F_{\text {st }}\right), 0.178$ and 0.155 , respectively. The genetic differentiation of Wright (1978) was high (Table 4).

The low differentiation in PRC x AR1 suggests that the broodstocks of $C$. macropomum may have been formed with offsprings from the same region or similar wild populations. However, this hypothesis is difficult to state because there has been no information about the origin of these individuals. Jacometo et al. (2010) and Lopes et al. (2009) also found high number of migrants per generation $-\mathrm{Nm}$ (24.30 and 13.35, respectively) for broodstocks of C. macropomum suggesting gene flow back- and forward into these stocks. 
Table 3. Analyses of molecular variance (AMOVA), source of variation (SV), mean Square (MS), coefficient of Variation $(\mathrm{CV})$, percentage of variation $(\% \mathrm{~V})$, distance (D) and genetic identity (I) in broodstock groups of Colossoma macropomum.

\begin{tabular}{lcccccc}
\hline Groups & SV & MS & CV & $\%$ V & D & I \\
\hline \multirow{3}{*}{ PRC x AR1 } & E.E & 26.588 & 0.48563 & $3.05^{*}$ & 0.025 & 0.975 \\
& D.E & 694.306 & 15.42901 & 96.95 & & \\
\cline { 2 - 7 } & Total & 720.894 & 15.91464 & 100 & & 0.846 \\
\multirow{2}{*}{ PRC x AR2 } & E.E & 96.765 & 3.50566 & $17.78^{*}$ & 0.155 & \\
\hline \multirow{3}{*}{ AR1 x AR2 } & D.E & 729.406 & 16.20901 & 82.22 & & 0.845 \\
\cline { 2 - 7 } & Total & 826.170 & 19.71467 & 100 & & 0.156 \\
\hline
\end{tabular}

${ }^{*} \mathrm{p}<0,05 . \mathrm{E} . \mathrm{E} .=$ between the broodstocks D.E. $=$ within the broodstocks. (PRC: Porto Real do Colégio, AL; AR1: Araujo 1, SE; AR2: Araujo 2, SE).

Table 4. $F_{\text {st }}$ (fixation index), $X^{2}$ test for $F_{\text {st }}$, genetic differentiation based on Wright (1978), and migrant number (Nm) in the groups from the broodstocks of Colossoma macropomum.

\begin{tabular}{ccccc}
\hline Groups & $\boldsymbol{F}_{\text {ST }}$ & Wright & $\boldsymbol{X}^{2}$ & Nm \\
\hline PRC x AR1 & $0.030^{*}$ & Low & 2.867 & 12.8 \\
PRC x AR2 & $0.178^{*}$ & High & 16.713 & 5.61 \\
AR1 x AR2 & $0.155^{*}$ & High & 12.376 & 5.07 \\
\hline
\end{tabular}

*p<0,05 (PRC: Porto Real do Colégio, AL; AR1: Araujo 1, SE; AR2: Araujo 2, SE.

The studies with molecular markers in fish stocks may be used in two specific areas: application in the fish production and genetic conservation. According to Allendorf and Ryman (1987) and Lacy (1987), the decline of genetic diversity in cultured stocks is the result of interaction between the founder effect, genetic drift and natural or artificial selection. The speed of this decline is influenced by reproductive management (parenting exchange, selection and number of parental used in the mating, reproductive system) (LOPES et al., 2009; POVH et al., 2008b; LOPERA-BARRERO et al., 2014) and the purpose of stock formation (fish farm, genetic breeding or restocking) (LOPES et al., 2009; POVH et al., 2011). In terms of genetic conservation, genetic information into restocking programs along with study of the ecology and monitoring is important to verify the potential of biological and genetic impacts of released fishes on wild populations (GARDNER et al., 2010). On the other hand, a major potential problem is the interaction between farmed specimens and wild population through accidental escapes or intentional releases from fish farms (AGUIAR et al., 2013). Thus, through molecular markers can guide management actions that allow the maintenance of genetic stocks in any productive and conservation purpose. In the case of our results, it is possible to affirm that PRC $\mathrm{x}$ AR1 form a single genetic broodstock. In contrast, PRC x AR2 and AR1 x AR2 were characterized as genetically different broodstocks and individuals can be exchanged between them.

The results in this experiment are source of important information for fish farm growers and researchers to manage reproductive stocks of Colossoma macropomum as well as their use in breeding and conservation programs. Thus, the dominant molecular markers were efficient in evaluating the genetic profile of these fish. However, despite the costs, we must consider additional 
investigations with co-dominant molecular techniques as the microsatellite markers which allow for more information from the captivity stocks and genetic conservation programs (RODRIGUEZRODRIGUEZ et al., 2010; LOPERA-BARRERO et al., 2014).

In conclusion, the fish broodstocks had high genetic variability with the highest values in the PRC and AR2. The group analysis indicated low genetic differentiation for PRC $\mathrm{x}$ AR and high for PRC x AR2 and AR1 x AR2.

\section{Acknowledgements}

The authors are thank to the members of Research Team of the PeixeGen for helping in this experiment under field conditions; the National Council of Research and Technological Development (CNPq), the Fishery and Aquaculture Ministry (MPA), and the Brazilian Company of Research and Development (EMBRAPA) for the funds, and to the fish growers who displayed the parental stocks of Colossoma macropomum.

\section{References}

AGUIAR, J.; SCHNEIDER, H.; GOMES, F.; CARNEIRO, J.; SANTOS, S.; RODRIGUES, L. R.; SAMPAIO, I. Genetic variation in native and farmed populations of Tambaqui (Colossoma macropomum) in the Brazilian Amazon: regional discrepancies in farming systems. Anais da Academia Brasileira de Ciências, Rio de Janeiro, v. 85, n. 4, p. 1439-1447, 2013.

ALLENDORF, F. W.; RYMAN, N. Genetic management of hatchery stocks. In: RYMAN, N.; UTTER, F. (Ed.). Population genetics and fishery management. Washington: University of Washington Press, 1987. p. 141-159.

ARAUJO-LIMA, C. A. R. M.; GOULDING, M. So fruitful fish: ecology, conservation, and aquaculture of the Amazon's Tambaqui. New York: Columbia University Press, 1997. $157 \mathrm{p}$.

AZRITA; HAFRIJAL SYANDRI; JUNAIDI. Genetic variation among asang fish (Osteochilus vittatus Cyprinidae) populations using random amplified polymorphic DNA (RAPD) markers. International
Journal of Fisheries and Aquatic Studies, New Delhi, v. 1, n. 6, p. 213-217, 2014.

BHAT, A. A.; HANIFFA, M. A.; MILTON, M. J.; PARAY, B. A.; DIVJA, P. R.; GOPALAKRISHNAN, A. Genetic variation of striped snakehead (Channa striatus Bloch, 1793) populations using random amplified polymorphic DNA (RAPD) markers. International Journal of Biodiversity and Conservation, Nairobi, v. 6, n. 5, p. 363-372, 2014.

EXCOFFIER, L.; LAVAL, G.; SCHNEIDER, S. Arlequin ver. 3.0: an integrated software package for population genetics data analysis. Evolutionary Bioinformatics Online, Auckland, v. 1, n. 2, p. 47-50, 2005.

EXCOFFIER, L.; SMOUSE, P. E.; QUATTRO, J. M. Analysis of molecular variance inferred from metric distances among DNA haplotypes: application to human mitochondrial DNA restriction data. Genetics, Bethesda, v. 131, n. 2, p. 479-491, 1992.

FALCONER, D. S. Introdução a genética quantitativa. Viçosa: UFV, 1987. 279 p.

FOOD AND AGRICULTURE ORGANIZATION OF THE UNITED NATIONS - FAO. Fishery Statistical Databases 2012. Roma: Food and Agriculture Organization of the United Nations, 2014. Available at: $<$ http://www.fao.org/3/a-i3720e/index.html $>$. Accessed at: 26 may 2015.

GARDNER, M. J.; COTTINGHAM, A.; PHILLIPS, N. M.; HESP, S. A.; CHAPLIN, J. A.; JENKINS, G. I. Biological performance and genetics of restocked and wild Black Bream in the Blackwood river estuary. Report to the West Australian Fish Foundation. Sidney: Project Funded by the Department of Fisheries, 2010. 60 p.

INSTITUTO BRASILEIRO DE GEOGRAFIA E ESTATÍSTICA - IBGE. Produção Pecuária Municipal 2013, Rio de Janeiro: IBGE, 2013. v. 41, p. 1-108.

JACOMETO, C. B.; LOPERA-BARRERO, N. M.; RODRIGUEZ-RODRIGUEZ, M. del P.; GOMES, P. C.; POVH, J. A.; STREIT JUNIOR, D. P.; VARGAS, L.; RESENDE, E. K.; RIBEIRO, R. P. Variabilidade genética em tambaquis (Teleostei: Characidae) de diferentes regiões do Brasil. Pesquisa Agropecuária Brasileira, Brasília, v. 45, n. 5, p. 481-487, 2010.

LACY, R. C. Loss of genetic diversity from managed populations: Interacting effects of drift, mutation, selection, and population subdivision. Conservation Biology, Malden, v. 1, n. 2, p. 143-158, 1987.

LOPERA-BARRERO, N. M.; POVH, J. A.; RIBEIRO, R. P.; GOMES, P. C.; JACOMETO, C. B.; LOPES, T. S. Comparación de protocolos de extracción de ADN con muestras de aleta y larva de peces: extracción modificada 
con cloruro de sodio. Ciencia e Investigación Agraria, Santiago, v. 35, n. 1, p. 76-86, 2008.

LOPERA-BARRERO, N. M.; REYES ALVAREZ, C. A.; RODRIGUEZ RODRIGUEZ, M del P.; POVH, J. A.; VARGAS, L.; STREIT JÚNIOR, D. P.; SIROL, R. N.; RIBEIRO, R. P. Diversidade genética e paternidade de progênies de Brycon orbignyanus obtidas por diferentes sistemas reprodutivos. Semina Ciências Agrárias, Londrina, v. 35, n. 1, p. 541-554, 2014.

LOPERA-BARRERO, N. M.; RIBEIRO, R. P.; POVH, J. A.; VARGAS, L.; FORNARI, D. C.; SIROL, R. N.; RODRÍGUEZ RODRÍGUEZ, M. del P. Diversidad genética de Brycon orbignyanus en el sistema reproductivo semi-natural, utilizando o marcador RAPD. Zootecnia Tropical, Maracay, v. 28, n. 1, p. 73-82, 2010a.

LOPERA-BARRERO, N. M.; VARGAS, L.; SIROL, R. N.; RIBEIRO, R. P.; POVH, J. A.; MANGOLIN, C. A. Caracterização genética de Brycon orbignyanus utilizando o sistema seminatural. Arquivo Brasileiro de Medicina Veterinária e Zootecnia, Belo Horizonte, v. 62, n. 1, p. 184-191, 2010b.

LOPES, T. S.; STREIT JÚNIOR, D. P.; RIBEIRO, R. P.; POVH, J. A.; LOPERA-BARRERO, N. M.; VARGAS, L.; PINTO FILHO, C.; QUEIROZ, J. R. Diversidade genética de estoques de reprodutores de Colossoma macropomum. Arquivo Brasileiro de Medicina Veterinária e Zootecnia, Belo Horizonte, v. 61, n. 3, p. 728-735, 2009.

MILLER, M. P. Tools for population genetic analyses (TFPGA): a Windows program for the analysis of allozyme and molecular population genetic data. Version 1.3. Flagstaff: Northern Arizona University, 1997. 33 p.

MINISTÉRIO DO MEIO AMBIENTE - MMA. Espécies ameaçadas de extinção, 2015. Disponível em: <http:// www.mma.gov.br/biodiversidade/especies-ameacadasde-extincao $>$. Acesso em: 26 maio 2015.

MINISTÉRIO DA PESCA E AQUICULTURA MPA. Boletim estatístico da pesca e aquicultura 2011. Brasília: Ministério da Pesca e Aquicultura, 2013. 60 p. Disponível em: <http://www.mpa.gov.br>. Acesso em: 26 maio 2015.

MOREIRA, A. A.; HILSDORF, A. W. S.; SILVA, J. V.; SOUZA, V. R. Variabilidade genética de duas variedades de tilápia nilótica por meio de marcadores microssatélites. Pesquisa Agropecuária Brasileira, Brasília, v. 42, n. 4, p. 521-526, 2007.

NEI, M. Estimation of the average heterozygosity and genetic distance from small number of individuals. Genetics, Bethesda, v. 89, n. 3, p. 583-590, 1978.
OLIVEIRA, C. A. L.; RIBEIRO, R. P.; STREIT JUNIOR, D. P.; POVH, J. A.; RESENDE, E. K. Melhoramento genético de peixes - uma realidade para piscicultura brasileira. Revista Panorama da Aquicultura, Laranjeiras, v. 130, n. 2, p. 38-47, 2012.

POVH, J. A.; LOPERA BARRERO, N. M.; RIBEIRO, R. P.; LUPCHINSKI JÚNIOR, E.; GOMES, P. C.; LOPES, T. S. Genetic monitoring of fish repopulation programs using molecular markers. Ciencia e Investigación Agraria, Santiago, v. 35, n. 1, p. 1-10, 2008 a.

POVH, J. A.; MOREIRA, H. L. M.; RIBEIRO, R. P.; PRIOLI, A. J.; VARGAS, L.; BLANCK, D. V.; GASPARINO, E.; STREIT JÚNIOR, D. P. Estimativa da variabilidade genética em tilápia do Nilo (Oreochromis niloticus) com a técnica de RAPD. Acta Scientiarum Animal Science, Maringá, v. 27, n. 1, p. 1-10, 2005.

POVH, J. A.; RIBEIRO, R. P.; LOPERA-BARRERO, N. M.; GOMES, P. C.; BLANCK, D. V.; VARGAS, L.; JACOMETO, C. B.; LOPES, T. S. Monitoramento da variabilidade genética de pacu, Piaractus mesopotamicus, do programa de aumento de estoque do rio Paranapanema. Arquivo Brasileiro de Medicina Veterinária e Zootecnia, Belo Horizonte, v. 61, n. 5, p. 1191-1195, 2009.

POVH, J. A.; RIBEIRO, R. P.; LOPERA-BARRERO, N. M.; JACOMETO, C. B.; VARGAS, L.; GOMES, P. C.; LOPES, T. S. Microsatellite analysis of pacu broodstocks used in the stocking program of Paranapanema River, Brazil. Scientia Agricola, Piracicaba, v. 68, n. 3, p. 308313, 2011.

POVH, J. A.; RIBEIRO, R. P.; SIROL, R. N.; STREIT JÚNIOR, D. P.; LOPERA-BARRERO, N. M.; VARGAS, L.; GOMES, P. C.; LOPES, T. S. Diversidade genética de pacu do rio Paranapanema e do estoque de um programa de repovoamento. Pesquisa Agropecuaria Brasileira, Brasília, v. 43, n. 2, p. 201-206, 2008 b.

RAYMOND, M.; ROUSSET, F. An exact test for population differentiation. Evolution, New York, v. 49, n. 6, p. 1280-1283, 1995.

RODRIGUEZ-RODRIGUEZ, M. del P.; LOPERABARRERO, N. M.; RIBEIRO, R. P.; POVH, J. A.; VARGAS, L.; SIROL, R. N.; JACOMETO, C. B. Diversidad genética de piracanjuba usada en programas de repoblación con marcadores microsatélites. Pesquisa Agropecuaria Brasileira, Brasília, v. 45, n. 1, p. 56-63, 2010.

TAVE, D. Inbreeding and brood stock management. Roma: FAO, 1999. 122 p.

WEIR, B. S.; COCKERHAM, C. C. Estimating F statistics for the analysis of population structure. Evolution, New York, v. 38, n. 6, p. 1358-1370, 1984. 
WILLIAMS, J. G. K.; RAFALSKI, J. A.; KUBELIK, A. R.; LIVAK, K. J.; TINGEY, S. V. DNA polymorphism amplified by arbitrary primers are useful as genetic markers. Nucleic Acids Research, Oxford, v. 18, n. 22, p. 6531-6535, 1990.

WORKMAN, P. L.; NISWANDER, J. L. Population studies on southwestern indian tribes. II. Local genetic differentiation in the Papago. American Journal of Human Genetics, Chicago, v. 22, n. 1, p. 24-49, 1970.
WRIGHT, S. Evolution and genetics of populations. Chicago: University of Chicago Press, 1978. 511 p.

YEH, F. C.; BOYLE, T. Y. Z.; XIYAN, J. M. PopGene Version 131: Microsoft Window-based freeware for population genetic analysis. Alberta: University of Alberta and Center for International Forestry Research, 1999. $29 \mathrm{p}$. 
